\title{
KEMAMPUAN MENULIS PANTUN DENGAN MENGGUNAKAN MODEL PEMBELAJARAN DOUBLE LOOP PROBLEM SOLVING DI SMP NEGERI 1 GUNUNGSITOLI UTARA
}

\author{
Trisman Harefa \\ Dosen Tetap IKIP Gunungsitoli (Yaperti Nias) \\ trisman_harefa@ymail.com
}

\begin{abstract}
Abstrak
Menulis pantun adalah serangkaian kegiatan seseorang untuk menuangkan pengetahuan atau pengalaman yang dimilikinya ke dalam bentuk tulisan yang ditandai oleh adanya bagian lampiran dan bagian isi sehingga memiliki keterikatan tertentu yang diperhatikan oleh penulis yakni tiap bait terdiri dari 4 baris, tiap baris terdiri atas 8 sampai 12 suku kata, sajaknya a-b-a-b atau bunyi akhir baris pertama sama dengan bunyi akhir baris ketiga, dan bunyi akhir baris kedua sama dengan bunyi akhir baris keempat, dan kedua baris pertama merupakan lampiran, sedangkan isinya terdapat pada kedua baris terakhir. Berdasarkan hasil penelitian, model pembelajaran Double Loop Problem Solving (DLPS) dapat meningkatkan kemampuan menulis pantun.
\end{abstract}

Kata kunci: menulis pantun, model pembelajaran double loop poblem solving (DLPS)

\begin{abstract}
Writing Rhyme is a series of activities someone to devote knowledge or their own experienced to writing form that in mark by the existence of the appendix and content part so has attachment must be attention by writer there are every temple consist of 4 line, every line consist of 8 to 12 syllable, rhyme $a-b-a-b$ or the sound of the end of first line same with the sound of the end third line, and the sound of the second line same with the sound of the fourth line, and two first line is consist attachment so it content there is in two the last line. Based on the research, double loop problem solving (DLPS) method can improving the ability of students writing Rhyme.
\end{abstract}

Keyword : writing rhyme, double loop poblem solving strategy

\section{PENDAHULUAN}

\subsection{Latar Belakang Masalah}

Menulis pantun disajikan dalam ranah konkret (menggunakan, mengurai, merangkai, memodifikasi, dan membuat) dan ranah abstrak (menulis, membaca, menghitung, menggambar, dan mengarang) sesuai dengan yang dipelajari di sekolah dan sumber lain yang sama dalam sudut pandang/teori. Berdasarkan hasil observasi yang dilakukan peneliti terhadap siswa dan juga hasil wawancara guru di SMP Negeri 1 Gunungsitoli Utara, permasalahan yang sering timbul dalam pembelajaran menulis pantun adalah siswa masih belum mampu dalam pemilihan kata yang tepat pada saat menulis pantun, struktur penulisan pantun masih kurang dipahami, siswa belum mampu menggunakan kreativitas dan daya imajinasi mereka sendiri dalam menulis pantun sedangkan tujuan dari pembelajaran menulis pantun itu sendiri ialah agar siswa mampu mengembangkan kreativitas dan daya imajinasinya untuk mengungkapkan gagasannya melalui kegiatan menulis pantun. Berkaitan dengan masalah di atas, penulis membuat solusi dalam pembelajaran dengan menggunakan model pembelajaran double loop problem solving (DLPS). Menurut Shoimi (2014:68) Double Loop Problem Solving adalah variasi dari pembelajaran dengan pemecahan masalah 
dengan penekanan pada pencarian kausal (penyebab) utama dari timbulnya masalah. Berdasarkan masalah tersebut, peneliti tertarik untuk melaksanakan penelitian ilmiah dengan mengangkat judul: "Peningkatan Kemampuan Siswa Menulis Pantun dengan Menggunakan Model Pembelajaran Double Loop Problem Solving (DLPS) di Kelas VII SMP Negeri 1 Gunungsitoli Utara Tahun Pembelajaran 2017/2018".

\subsection{Rumusan Masalah}

Hasil penelitian ini diharapkan bermanfaat kepada:

1. Peneliti, menambah wawasan dan jawaban dari permasalahan yang ada dan pengalaman langsung menerapkan model pembelajaran Double Loop Problem Solving (DLPS) sebagai acuan menjalankan tugas sebagai tenaga pengajar dimasa yang akan datang.

2. Bagi guru, mengembangkan dan meningkatkan kemampuan guru.

3. Bagi siswa, mengembangkan kreativitas dan kemandirian siswa, membangkitkan minat dan rasa ingin tahu siswa, memberikan pengalaman dalam meningkatkan kualitas proses dan hasil belajar siswa.

\subsection{Manfaat Penelitian}

Berdasarkan rumusan masalah, manfaat penelitian ini adalah: "Mendeskripsikan kemampuan menulis pantun dengan menerapkan model pembelajaran Double Loop Problem Solving (DLPS) siswa Kelas VII SMP Negeri 1 Gunungsitoli Utara Tahun Pembelajaran 2017/2018."

\section{METODE}

Penelitian ini merupakan penelitian tindakan kelas (Classroom actionresearch). PTK dilakukan dengan menggunakan pendekatan mixing yaitu gabungan antara pendekatan kualitatif dan kuantitatif:

\section{Analisis data kuantitatif}

Teknik analisis data kuantitatif tes esay (menulis pantun) dapat dilakukan dengan menempuh langkah-langkah sebagai berikut:

a. Penskoran. Skor diberikan sesuai dengan kisi-kisi instrumen.

b. Penjumlahan skor. Setelah lembaran hasil menulis pantun siswa diberi skor sesuai dengan kisi-kisi instrumen, maka setiap skor dijumlahkan untuk mendapat skor akhir.

c. Penentuan Penilaian. Penentuan batas minimal kelulusan dan penilaian nilai tertentu dapat dilakukan dengan perhitungan sistem pembobotan,

d. Mencari rata-rata

Dalam menganalisis data yang ada peneliti mengklasifikasikan persentase semua persen. Peneliti menggunakan rumus mencari rata-rata yaitu: Djamarah (2010:306) mengemukakan rumus mencari rata-rata yaitu:

$\mathrm{M}=\frac{\sum X}{N}$

Keterangan:

$\mathrm{M}=$ Mean (Nilai rata-rata)

$\sum X=$ Jumlah nilai total yang diperoleh dari hasil penjumlahan nilai setiap individu.

$N=$ Banyaknya individu.

2. Analisis data kualitatif

Setelah dilakukan analisis data kuantitatif hasil tes menulis pantun, maka diteruskan dengan analisis data kualitatif (hasil observasi) dengan menempuh tiga tahapan berikut yaitu:

a. Reduksi data, yaitu menyeleksi dan mengelompokkan data berdasarkan informasi dan diorganisasikan sesuai dengan pertanyaan peneliti. 
b. Paparan data, yaitu bahwa data yang sudah terorganisasi dikelompokkan atau dideskripsikan sampai bermakna dalam bentuk tabel atau grafik ataupun dinarasikan.

c. Penyimpulan, yaitu bahwa berdasarkan paparan yang telah dibuat ditarik suatu kesimpulan dalam bentuk pernyataan atau formula singkat.

\section{HASIL DAN PEMBAHASAN}

Penelitian ini dilaksanakan di SMP Negeri 1 Gunungsitoli Utara, Kota Gunungsitoli.

\section{Pertemuan Pertama}

Pelaksanaan siklus I pertemuan pertama dilakukan dengan empat prosedur yaitu: perencanaan, tindakan, observasi, dan refleksi untuk lebih jelasnya dapat diuraikan sebagai berikut:

a. Perencanaan

Peneliti bersama guru mata pelajaran bahasa Indonesia menyamakan persepsi dalam menyusun RPP, silabus, daftar hadir siswa, kisi-kisi soal, menyiapkan lembar observasi siswa dan peneliti, dan menyiapkan materi pembelajaran pada saat peneliti mengadakan penelitian.

b. Tindakan

Kegiatan yang dilakukan dalam tindakan ini adalah Peneliti membuka pembelajaran dengan mengucapkan salam dan menyuruh salah seorang siswa untuk memimpin doa sebelum pembelajaran dimulai. Peneliti memotivasi siswa kearah pembelajaran agar siswa mampu menulis pantun sesuai dengan struktur penulisan pantun yang baik dan benar berdasarkan syarat-syarat pantun yang telah ditetapkan. Peneliti menjelaskan langkah-langkah model pembelajaran Double Loop Problem Solving (DLPS)

c. Observasi
Kegiatan yang dilakukan oleh guru mata pelajaran bahasa Indonesia yang membantu peneliti dalam melaksanakan penelitian di kelas dengan tujuan untuk mengamati kegiatan aktivitas siswa dan peneliti selama mengikuti pembelajaran menulis pantun pada siklus I pertemuan pertama. Hasil observasi siswa.

d. Refleksi

Kegiatan yang dilakukan dalam refleksi ini adalah memperbaiki kelemahan-kelemahan yang terjadi selama proses pembelajaran pada siklus I pertemuan pertama baik yang dilakukan oleh peneliti maupun siswa yang dilakukan oleh siswa. Maka, peneliti perlu mengadakan refleksi sebagai berikut:

1) Peneliti sebaiknya jeli dalam memperhatikan siswa yang ribut dan mengganggu temannya dan memberikan sangsi kepada siswa yang tidak mendengarkan.

2) Peneliti sebaiknya memberikan applause atau penghargaan kepada siswa yang memberikan tanggapan dan saran agar peserta didik termotivasi untuk belajar.

3) Peneliti perlu melanjutkan pembejaran pada pertemuan berikutnya dengan tujuan untuk melihat kemampuan siswa dalam menulis pantun.

\section{Pertemuan Kedua}

Pelaksanaan siklus I pertemuan kedua dilaksanakan pada les pertama dan kedua pada mata pelajaran bahasa dan sastra Indonesia

1. Perencanaan

Pada tahap ini peneliti melanjutkan siklus pertama sebagai tindakan selanjutnya.

2. Tindakan

Peneliti memberitahukan kelemahan siswa pada pertemuan pertama serta 
memotivasi siswa agar lebih serius dalam belajar. Kemudian peneliti mengadakan evalausi kemampuan siswa.

3. Observasi

1. Lembar observasi siswa. Berdasarkan hasil observasi siswa pada siklus I pertemuan kedua maka hasil observasi yang diperoleh siswa dengan baik.

2. Lembar observasi peneliti. Berdasarkan hasil observasi maka kegiatan yang dilaksanakan atau yang.

4. Refleksi

Setelah mengadakan pembelajaran terhadap siklus I maka, peneliti mengadakan refleksi terhadap kelemahan-kelemahan yang terjadi pada pembelajaran

1. Peneliti melanjutkan tindakan pada siklus berikutnya atau siklus II dengan tujuan untuk meningkatkan kemampuan siswa menulis pantun dan memperbaiki kelemahan-kelemahan pada siklus sebelumnya.

2. Peneliti mengoptimalkan sebaiknya pembelajaran agar tujuan pembelajaran tercapai dan tidak mengganggu proses pembelajaran yang lain.

3. Peneliti perlu mengulas kembali penjelasan kepada peserta didik tentang langkah-langkah pembelajaran Double Loop Problem Solving terhadap keterampilan menulis pantun.

\section{Siklus Kedua}

Pelaksanaan siklus II pertemuan pertama dilakukan peneliti pada siklus II pertemuan pertama ini adalah sebagai berikut:

1. Perencanaan

2. Tahap perencanaan siklus II meliputi silabus, RPP, materi pembelajaran, lembar observasi peneliti maupun siswa, dan daftar hadir siswa.

3. Tindakan.

4. Peneliti melaksanakan pembelajaran sesuai dengan (RPP) yang sudah di siapkan

5. Observasi

Berdasarkan hasil tersebut ada beberapa kelebihan dan kelemahan siswa yaitu:

a) Kelebihan siswa yaitu: keaktifan siswa lebih meningkat

b) Kelemahan siswa yaitu: tidak semua siswa dalam pembelajaran adanya sebagian siswa yang mengganggu temannya dalam proses pembelajaran.

\section{Refleksi}

Setelah mengadakan pembelajaran terhadap siklus II pertemuan pertama maka, peneliti mengadakan refleksi terhadap kelemahan yang terjadi pada pembelajaran pertemuan ke II.

\subsection{Pertemuan Kedua}

Pelaksanaan siklus II pertemuan kedua dilakukan dengan empat tahapan yaitu: perencanaan, tindakan, observasi, dan refleksi untuk lebih jelasnya dapat dipaparkan sebagai berikut:

a) Perencanaan

Peneliti mengoptimalkan waktu pembelajaran, menyiapkan perangkat pembelajaran di antaranya: silabus, daftar hadir siswa, materi pembelajaran menulis pantun, kisikisi soal, daftar nilai siswa, lembar observasi siswa dan peneliti, dan contoh pantun.

b) Tindakan. Kegiatan yang dilakukan pada tahap tindakan ini adalah menjelaskan materi pembelajaran menulis pantun dengan menerapkan model pembelajaran.

c) Observasi. Ada dua hal yang perlu diperhatikan dalam kegiatan observasi dalam penelitian ini yaitu mengamati aktivitas siswa dan 
aktivitas peneliti pada siklus II pertemuan kedua.

\section{Jawaban Umum Atas Permasalahan Pokok Penelitian}

Berdasarkan model pembelajaran yang diterapkan oleh peneliti pada proses pembelajaran menulis pantun maka jawaban umum yang dapat diberikan adalah dengan menggunakan model pembelajaran Double Loop Problem Solving dapat meningkatkan kemampuan siswa menulis pantun di kelas VII SMP Negeri 1 Gunungsitoli Utara dengan nilai rata-rata kemampuan siswa pada siklus I sebesar 67,91 dan pada siklus II terjadi peningkatan menjadi 85 .

\section{Analisis dan Penafsiran Temuan Penelitian}

Setelah diadakan tindakan pembelajaran pada siklus I dan siklus II berdasarkan tahap-tahap penelitian tindakan kelas maka peneliti menganalisis hasil temuan penelitian menulis pantun dengan menggunakan model pembelajaran Double Loop Problem Solving yaitu:

1) Hasil kemampuan siswa kelas VII SMP Negeri 1 Gunungsitoli Utara menulis pantun dengan menggunakan model pembelajaran Double Loop Problem Solving yaitu: pada siklus I nilai rata-rata kemampuan siswa menulis pantun sebesar 67,70 dengan jumlah nilai secara keseluruhan sebesar 1625, nilai terendah 45 dan nilai tertinggi 90, dengan ketuntasan siswa sebanyak 8 orang dengan persentase

2) Hasil pada lembar observasi peneliti pada siklus I pertemuan pertama kegiatan yang terlaksana sebanyak 10 item dengan persentase $47,61 \%$ dan kegiatan yang tidak terlaksana 11 item dengan persentase $52,38 \%$. Sedangkan pertemuan kedua kegiatan peneliti yang terlaksana sebanyak 15 item dengan persentase $71,42 \%$ dan kegiatan yang tidak terlaksana sebanyak 6 item dengan persentase $28,57 \%$. Selanjutnya, siklus II pertemuan pertama kegiatan yang terlaksana sebanyak 17 item dengan persentase $80,95 \%$ dan kegiatan yang belum terlaksana 4 item dengan persentase $16,66 \%$ sedangkan pertemuan kedua sebanyak kegiatan yang terlaksana 19 item dengan persentase $90,47 \%$ dan tidak terlaksana 2 dengan persentase $9,52 \%$.

3) Hasil pada lembar observasi siswa pada siklus I pertemuan pertama sebesar $63,69 \%$ dengan keaktifan siswa 6 orang dengan persentase $25 \%$ dan yang tidak aktif sebanyak 18 orang siswa dengan persentase $75 \%$ dan pertemuan kedua hasil observasi siswa sebesar $73,69 \%$ dengan keaktifan siswa 9 orang dengan persentase $37,5 \%$ dan yang tidak aktif sebanyak 15 orang siswa dengan persentae $62,5 \%$. Sedangkan, pada siklus II pertemuan pertama hasil observasi siswa sebesar 89,58\% dengan keaktifan siswa 13 orang dengan persentase $54,16 \%$ dan yang tidak aktif sebanyak 11 orang siswa dengan persentae 45,83\%, dan pertemuan kedua sebesar 95,57\% dengan keaktifan siswa 18 orang dengan persentase $75 \%$ dan yang tidak aktif sebanyak 6 orang siswa dengan persentae $25 \%$.

\section{Implikasi Temuan Penelitian}

Penerapan hasil temuan penelitian ini adalah di SMP Negeri 1 Gunungsitoli Utara dapat membantu peserta didik terhadap proses pembelajaran yang diterima kepada guru sehingga adanya komunikasi yang baik terhadap siswa yang satu dengan yang lain dan kepada guru bidang studi. Temuan penelitian tersebut dapat juga membawa dampak kepada peneliti bahwa keberhasilan 
dalam suatu penelitian berpengaruh terhadap hasil yang telah diperoleh di lapangan sehingga dapat digunakan sebagai perbandingan penelitian yang akan meneliti berikutnya.

Selanjutnya, penerapan hasil temuan penelitian ini menunjukkan bahwa kemampuan mengembangkan keterampilan menulis pantun ditentukan oleh faktor pemahaman siswa dan motivasi siswa untuk menulis, dan persepsi siswa terhadap cara guru mengajar. Implikasi tersebut dapat digunakan sebagai dasar untuk menunjukkan bahwa kemampuan menulis pantun dapat ditingkatkan melalui pembelajaran dengan menggunakan model pembelajaran Double Loop Problem Solving.

\section{Keterbatasan Hasil Analisis dan Penafsiran Temuan Penelitian}

Pada dasarnya keabsahan temuan penelitian tidaklah mutlak, disebabkan karena ada sejumlah keterbatasan baik dari hasil yang diperoleh maupun dari penerapan peneliti di lokasi penelitian. Berdasarkan hasil analisis yang ditemukan pada siklus I dan II pada dasarnya keterbatasan maksimal yang dicapai adalah $100 \%$ tetapi berdasarkan hasil yang diperoleh hanya $85 \%$ hal ini terjadi peningkatan pada siklus II. Oleh sebab itu, ada beberapa keterbatasan peneliti yaitu:

a. Keterbatasan kemampuan peneliti menyediakan sarana dan prasarana yang dibutuhkan oleh siswa SMP Negeri 1 Gunungsitoli Utara disebabkan karena keterbatasan dana dari peneliti.

b. Penelitian ini, hanya dilaksanakan di kelas VII SMP Negeri 1 Gunungsitoli Utara dengan jumlah siswa 24 orang.

\section{KESIMPULAN}

Berdasarkan hasil temuan penelitian siklus I dan siklus II yaitu pada siklus I diperoleh hasil prestasi belajar siswa adalah nilai terendah 50 dan nilai nilai tertinggi 90 dengan rata-rata nilai sebesar 67,91. Sedangkan pada siklus II nilai terendah 80 dan nilai tertinggi 100 dengan rata-rata nilai sebesar 85 , hasil observasi siswa pada siklus I sebesar $73,69 \%$ dan pada siklus II sebesar 95,57\% sedangkan, hasil observasi peneliti siklus I sebesar $71,42 \%$ dan siklus II sebesar 90,47\%. Data ini menunjukkan bahwa prestasi belajar siswa pada siklus II lebih baik dari pada siklus I, dengan menggunakan model pembelajaran Double Loop Problem Solving dapat meningkatkan kemampuan menulis pantun siswa kelas VII SMP Negeri 1 Gunungsitoli Utara Tahun Pembelajaran 2017/2018, model pembelajaran Double Loop Problem Solving dapat memberi motivasi belajar kepada siswa kelas VII Negeri 1 Gunungsitoli Utara Tahun Pembelajaran 2017/2018 dalam menulis pantun.

\section{DAFTAR PUSTAKA}

Anisah. (2017). pengaruh Model Double Loop Problem Solving (DLPS) terhadap Kemampuan Berfikir Kritis Matematika Pada Materi Persamaan Linear Satu Variabel Siswa Kelas VII MTs.

Arikunto, S. (2008). Prosedur Penelitian Suatu Pendekatan Praktek. Jakarta: Rineka Cipta.

Darmadi. (1996). Meningkatkan Kemampuan Menulis Panduan untuk Mahasiswa dan Calon Mahasiswa Yogyakarta. Yogyakarta: Andi Yogyakarta.

Djamarah, S. B. (2010). Guru dan Anak Didik dalam Interaksi Edukatif. Jakarta: Rineka Cipta. 
Djiwandono, S. (2010). Tes Bahasa Pegangan Bagi Pengajar Bahasa. Malang: PT Indeks.

Elina Syarif, Z. S. (2009). Pembelajaran Menulis. Jakarta: Departemen Pendidikan Nasional.

Kosasih, E. (2008). Apresiasi Sastra Indonesia Puisi, Prosa, Novel. Jakarta: Nobel Edumedia.

Nurgiantoro, B. (2010). Penilaian dalam Pengajaran Bahasa Indonesia. Yogyakarta: BFFE.

Priyatni, P. (2008). Contekstual Teaching and Learning Bahasa Indonesia Sekolah Menengah Pertama. Jakarta: Depdiknas.

Sumarno. (2009). Pembelajaran menulis. Jakarta: Gramedia. 